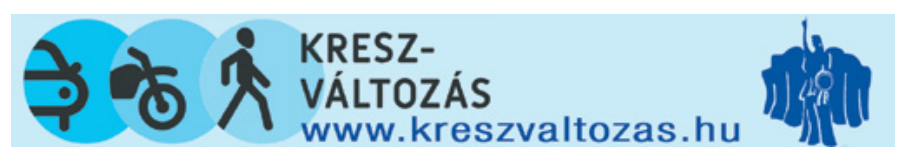

\title{
Közúti baleseti sérülések kockázata Magyarországon
}

A Közlekedéstudományi Szemle rendszeresen foglalkozik a közúti közlekedés biztonsági kérdéseivel. Az ORFK-OBB - feladatából adódóan - kiemelt jelentőségűnek minősíti e témakört. Rendszeres mellékletünk jó alkalmat kínál a helyzetértékelésen túlmenően a trendek bemutatására, illetve a különböző szempontokból válogatott országokkal, országcsoportokkal való összehasonlításra.

DOI 10.24228/KTSZ.2020.5.4

\section{Dr. Jankó Domokos}

e-mail: balesetelemzes@gmail.com

\section{BEVEZETÉS}

Az egyes országok objektív közúti közlekedésbiztonsági helyzetének jellemzésére különböző - számított - mutatók használhatók. Legismertebb a „közlekedési halálozási arány” vagy „baleseti mortalitási mutató”, ami az átlagosan egymillió lakosra jutó halálos közlekedési baleseti áldozatok számát jelenti. Ez a szám tulajdonképpen egy kockázati mutató, ami jelzi, hogy az adott ország közúthálózatán milyen esélye van a közlekedőnek, hogy közúti balesetben halálosan megsérül. Minél kisebb ez a szám, ebből a szempontból annál biztonságosabbnak tekinthető az ország közúti közlekedése. Az 1. táblázatban néhány szomszédos ország adata mellett az EU átlagot és a legjobbak között számontartott svéd mutatót is közöljük. [1]. A 2010. évi adat a 2011-2020. évekre vonatkozó 10 éves EU (egyben a magyar) közlekedésbiztonsági stratégiai program bázisa. A mutatók 2019. évre történt csökkenésének mértékét a táblázat utolsó oszlopában látjuk. A csökkenések lényegében a programidőszak alatt kifejtett közlekedésbiztonsági tevékenység eredményességét mutatják.
A halálos sérülés kockázatának mutatója az EU tagországaiban 2019-re összesen 25\%-kal csökkent, ami önmagában természetesen kedvező, a 2020-ra kitűzött 50\%-os célkitűzéstől azonban várhatóan jelentősen elmarad. Mind a hét kiválasztott országban - különböző bázisról indulva - javultak a kockázati értékek. Sajnálatos módon a legkisebb csökkenést Magyarország érte el, a hét közül a legnagyobbat Szlovákia.

$\begin{aligned} & \text { 1. táblázat: Meghalt/millió lakos kockáza- } \\
& \text { ti mutató értékei } 2010 \text { és } 2019 \text { években }\end{aligned}$
\begin{tabular}{|l|c|c|c|}
\hline & 2010 & $\mathbf{2 0 1 9}$ & $\begin{array}{c}\text { Csökkenés } \\
(\%)\end{array}$ \\
\hline Magyarország & 74 & 62 & $-16 \%$ \\
\hline Románia & 117 & 96 & $-18 \%$ \\
\hline Svédország & 28 & 22 & $-21 \%$ \\
\hline Csehország & 77 & 58 & $-25 \%$ \\
\hline EU átlag & 68 & $\mathbf{5 1}$ & $-25 \%$ \\
\hline Horvátország & 99 & 73 & $-26 \%$ \\
\hline Ausztria & 65 & 47 & $-29 \%$ \\
\hline Szlovákia & & 45 & $-31 \%$ \\
\hline
\end{tabular}




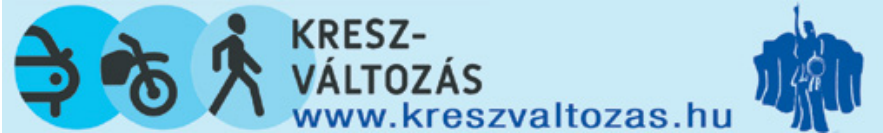

2. táblázat: Magyarországon 2017-2019. között megsérült férfiak és nők száma és számarányał

\begin{tabular}{|c|c|c|c|c|c|c|c|c|}
\hline & \multicolumn{2}{|c|}{$\underset{\text { (fö) }}{\text { MEGHALT }}$} & \multicolumn{2}{|c|}{$\underset{\text { (fö) }}{\text { SÚLYOSAN SÉRÜLT }}$} & \multicolumn{2}{|c|}{$\underset{\text { (fö) }}{\text { KÖNNYEN SÉRÜLT }}$} & \multicolumn{2}{|c|}{$\begin{array}{c}\text { ÖSSZES SÉRÜLT } \\
\text { (fö) }\end{array}$} \\
\hline & Férfi & Nő & Férfi & Nő & Férfi & Nő & Férfi & Nő \\
\hline 2017-2019. évek & 1359 & 500 & 10467 & 6126 & 27267 & 20843 & 39093 & 27469 \\
\hline Évi átlag (fö/év) & 453 & 167 & 3489 & 2042 & 9089 & 6948 & 13031 & 9157 \\
\hline Összes átlag (fö/év) & \multicolumn{2}{|c|}{620} & \multicolumn{2}{|c|}{5531} & \multicolumn{2}{|c|}{16036} & \multicolumn{2}{|c|}{22187} \\
\hline Férfi/nő arány (\%) & \multicolumn{2}{|c|}{$73 \% / 27 \%$} & \multicolumn{2}{|c|}{$63 \% / 37 \%$} & \multicolumn{2}{|c|}{$57 \% / 43 \%$} & \multicolumn{2}{|c|}{$59 \% / 41 \%$} \\
\hline
\end{tabular}

* A hazai személysérüléses közúti közlekedési baleseti adatok forrása: Központi Statisztikai Hivatal baleseti adatbázisa. (kezelö program: web-bal, MK Zrt.)

A mortalitási index mellett még további két kockázati mutató használatos a nemzetközi szakirodalomban. Az egyiknél a viszonyítási alap az ország gépjármủállománya, a másiknál pedig az ország közútjain mérhető forgalmi teljesítmény. Szakmai szempontból leginkább alkalmas kockázati mutatónak tekinthető az egységnyi (1 milliárd járműkilométer) közúti forgalmi teljesítményre vetített halálos áldozatok száma. Magyarországon a teljes hazai közúthálózatra számított éves futásteljesítmények megbízható adatai nem állnak rendelkezésre, így ilyen - nemzetközi összehasonlításra alkalmas mutatóval - nem lehet számolni. Az [1] szakanyagban közreadott rangsorban a magyar adat nem szerepel. A cikk további részeiben csak a közlekedési halálozási mutatóval foglalkozom.

Az előzőekben bemutatott közlekedési halálozási mutató 2019. évi értéke az ország teljes lakosságára számított átlagos halálozási kockázatot jelenti. $\left(62^{\star} 10^{-6}\right)$. A 2017-2019. közötti hároméves időszak évi átlagával számolva a kockázat $63^{*} 10^{-6}$. A tanulmányban azt vizsgálom, hogyan alakul a számított - elsősorban a halálos - sérülési kockázat férfiak és nők között, illetve a különböző életkori csoportokban.

\section{FÉRFIAK - NÖK SZÁMÁNAK ARÁNYA A KÖZÜTI BALESETI SÉRÜLTEK KÖZÖTT}

A vizsgált időszak a 2017-2019. közötti hároméves KÖZLEKEDÉSBIZTONSÁGI AKCIÓPROGRAM időszaka, ami egyben az EU és Magyarország 10 éves stratégiai megelözési programjában az utolsó - 2020. évet megelőző - három év ${ }^{1}$. A 2. táblázat a különbözö kimenetelü sérülések számát tartalmazza férfi és női sérült bontásban. A 2. táblázat utolsó sora mutatja a nemek számarányát a sérültek között. Megfigyelhetö, hogy a sérülés kimenetelétől függően jelentősen változik a nemek aránya. A legsúlyosabb sérültek között a nők aránya Magyarországon $27 \%$, a súlyos sérülés esetén $37 \%$, könnyủ kimenetelü sérülés esetén pedig $43 \%$. (1. ábra)

Az adatok szerint tehát a halálosan megsérült személyek között a nők aránya $27 \%$, vagyis a vizsgált három év alatt - az évente átlagosan meghalt 620 fö között 167 nő volt és 453 férfi. A férfiak száma tehát lényegesen nagyobb a halálosan megsérültek között, mint a nőké. A vizsgált időszakban a női áldozatok számának 2,7-szerese volt férfi áldozat, ami meglehetősen nagy különbség és amit nem indokol a népességben meglévő nemek aránya (4. táblázat).

A [2] szakanyagban találtam svédországi adatot a halálosan megsérültek (meghaltak) számának nemek szerinti megoszlására. Svédországban 2017-ben 253 fö halt meg közúti baleset következtében, közülük 57 nő és 196 férfi volt az áldozatok száma. Az arányok tehát

1 Nem érthető, hogy miért úgy választották meg a hazai részprogramok időszakait, hogy azok együttesen nem fedik le a 2011 - 2020. évek közötti teljes 10 éves programidőszakot? A 2020.év még része a 10 éves hosszútávú megelözési tervnek, de már része a következő - 2020-2020. közötti - hároméves akcióprogramnak is. 


\section{Fesz-

\section{1. ábra: Férfiak - nők számaránya a sérültek között Magyarországon (2017-2019)}

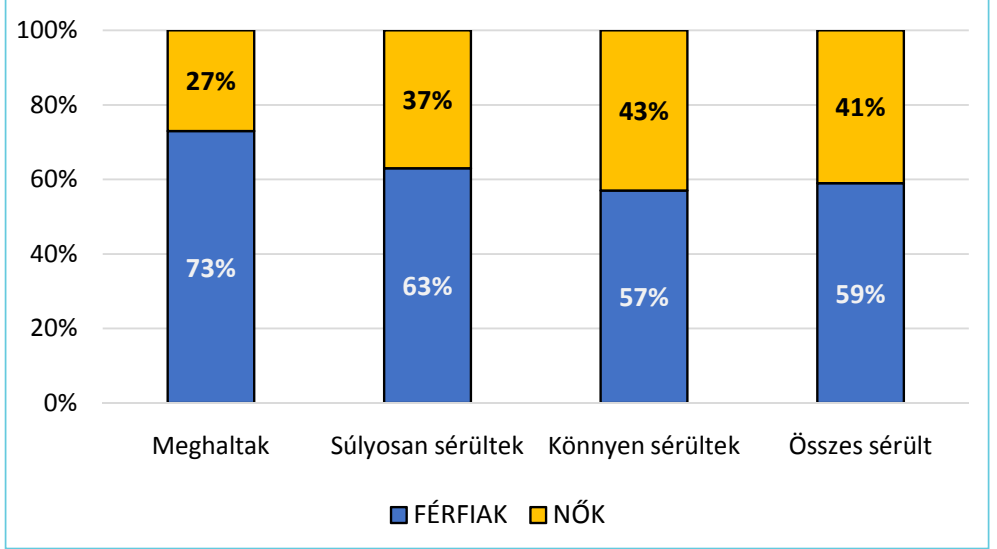

esetek következtében - a különböző életkori csoportokba tartozó megsérültek számát, férfi és nő bontásban. A 4. táblázat tartalmazza a népesség számát a különböző életkori csoportokban. (Forrás: KSH)

A 3. és 4. táblázatban található adatokkal számítottam a halálos, súlyos, valamint a könnyü sérülés kockázatait.

3. táblázat: Közúti baleseti sérültek száma országosan a 2017-2019. években (fő)

\begin{tabular}{|l|r|r|r|r|r|r|r|r|r|}
\hline & \multicolumn{3}{|c|}{ MEGHALT } & \multicolumn{3}{c|}{ SÚLYOSAN SÉRÜLT } & \multicolumn{3}{c|}{ KÖNNYEN SÉRÜLT } \\
\hline $\begin{array}{l}\text { ÉLETKORI CSOPORTOK } \\
\text { (Év - Év) }\end{array}$ & Férfi & Nö & Összes & Férfi & Nő & Összes & Férfi & Nő & Összes \\
\hline $0-17$ & 29 & 22 & 51 & 598 & 361 & 959 & 3380 & 2813 & 6193 \\
\hline $18-24$ & 109 & 37 & 146 & 1198 & 546 & 1744 & 4240 & 2744 & 6984 \\
\hline $25-44$ & 402 & 101 & 503 & 3828 & 1473 & 5301 & 10098 & 7118 & 17216 \\
\hline $45-64$ & 482 & 155 & 637 & 3364 & 2079 & 5443 & 6475 & 5370 & 11845 \\
\hline $65-75$ & 206 & 84 & 290 & 982 & 1078 & 2060 & 2049 & 1875 & 3924 \\
\hline $76-$ & 130 & 100 & 230 & 497 & 589 & 1086 & 1025 & 922 & 1947 \\
\hline Összes & 1359 & 500 & 1859 & 10467 & 6126 & 16593 & 27267 & 20843 & 48110 \\
\hline Évi átlag & 453 & 167 & 620 & 3489 & 2042 & 5531 & 9089 & 6948 & 16037 \\
\hline
\end{tabular}

$77 \% / 23 \%$, vagyis a jelzett országban a meghalt nők számának 3,4-szerese volt férfi. Ez az arány Magyarországon 2,7-szeres, vagyis arányosan kevesebb nő sérült meg halálosan Svédországban, mint Magyarországon, ugyanabban az évben.

\section{A BALESETI SÉRÜLÉSEK KOCKÁ- ZATA A KÜLÖNBÖZÖ ÉLETKORI CSOPORTOKBAN}

A kockázatok számításához szükség van a sérültek életkorára és a kiválasztott életkori csoportokban a népesség (lakosszám) nagyságára. A 3. táblázatban foglaltam össze a 2017-2019. években - közúti közlekedési bal-
4. táblázat: Népesség az életkori csoportokban $\left(\mathrm{foó}^{\star}\right.$ 1000) (2017)

\begin{tabular}{|l|c|c|c|c|c|}
\hline $\begin{array}{c}\text { Életkori } \\
\text { csoport } \\
\text { (Év-Év) }\end{array}$ & Férfi & Nö & Összes & Férfi\% & Nö\% \\
\hline $0-17$ & 880 & 833 & 1713 & $51 \%$ & $49 \%$ \\
\hline $18-24$ & 410 & 388 & 798 & $51 \%$ & $49 \%$ \\
\hline $25-44$ & 1397 & 1348 & 2745 & $51 \%$ & $49 \%$ \\
\hline $45-64$ & 1258 & 1362 & 2620 & $48 \%$ & $52 \%$ \\
\hline $65-75$ & 469 & 663 & 1132 & $41 \%$ & $59 \%$ \\
\hline $76-$ & 248 & 524 & 772 & $32 \%$ & $68 \%$ \\
\hline Összesen & 4658 & 5124 & 9782 & $48 \%$ & $52 \%$ \\
\hline
\end{tabular}




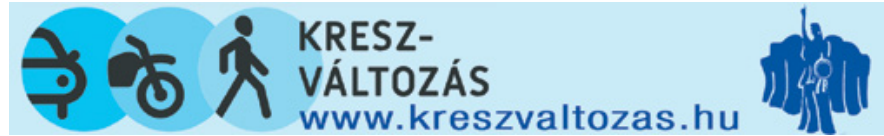

2. ábra: Halálos közúti baleseti sérülés kockázata

Magyarországon (2017-2019)

$$
\text { 岕 }
$$$$
\begin{array}{r}
12 \\
100 \\
80 \\
60 \\
40 \\
20
\end{array}
$$

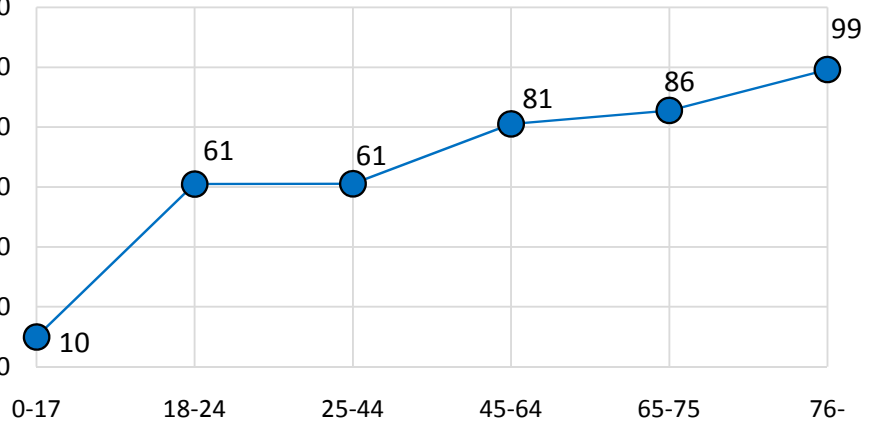

ÉLETKORI CSOPORTOK (ÉV - ÉV)

\section{HALÁLOS BALESETI SÉRÜLÉS KOCKÁZATA MAGYARORSZÁ- GON}

A teljes népességre számított halálos sérülés kockázata a vizsgált hároméves időszak átlaga szerint: $63^{\star} 10^{-6} \mathrm{~A} 2$. ábrán a halálos baleseti sérülés számított kockázati mutatói láthatók a választott életkori csoportokban ${ }^{2}$. A halálos baleseti sérülés legnagyobb kockázata a 75 évesnél idősebb lakosoknak van $\left(99^{\star} 10^{-6}\right)$, míg a legkisebb kockázat a 17 évesnél fiatalabb korosztálynál számítható. Megfigyelhető, hogy Magyarországon a halálos sérülés kockázata a közúti közlekedésben, az életkor növekedésével egyre nagyobb. A 18-24 évesek és 25-44 évesek kockázata gyakorlatilag azonos nagyságú és a teljes népesség átlagos kockázatához közeli érték.

Megállapítható, hogy mind a teljes népességre, mind az egyes életkori csoportok tagjaira számítva, a halálos közlekedési baleseti sérülés kockázata Magyarországon elfogadhatatlanul nagy, különösen az idősebbek körében.

2 Az életkori csoportokat nem teljesen önkényesen választottam. Egy svéd tanulmányban ezt a csoportositást használták és a hazai adatokkal történő összehasonlíthatóság érdekében használom én is ezt a csoportositást. A hivatkozott svéd anyag: Analysis of Road Safety Trends 2017. TRAFIKVERKET. Swedish Transport Administration. 2018. April. https://trafikverket.ineko.se/
A következő fejezetben a svéd és a magyar adatokat hasonlítom össze.

\section{HALÁLOS SÉRÜLÉS KOC- KÁZATAINAK ÖSSZEHASON- LÍTÁSA}

Felmerülhet a kérdés, a közúti közlekedésbiztonság kérdéskörében miért éppen Svédország adataival hasonlítom össze a hazai adatokat, hiszen azon kívül, hogy a lakosságszám a magyarokéval közel azonos, ezen a téren a két ország - közlekedésbiztonsági szempontból összemérhető adataiban nagy különbségek vannak. A válasz az, hogy egyrészt a svédországi közlekedésbiztonsági helyzet kezelése példaértékü, másrészt megbízható adatok állnak rendelkezésre [2].

Az EU tagországok baleseti halálozási adatainak rangsorában - 2017-ben - Svédország az 1. helyen állt (25 meghalt/millió lakos), Magyarország pedig távol az első helytől, a 21 . helyen (64 meghalt/millió lakos). 2018-ban "rontott” Svédország, nőtt az áldozatok száma, ezzel az ország az említett nemzetközi rangsorban az 5. helyre került. A hazai adat 2018-ban nem romlott, maradt 64, de ezzel a 2018. évi listában mégis hátrébb, a 23. helyre kerültünk. (Az egy före jutó GDP szerinti rangsorban - talán nem teljesen meglepő módon - ugyanezek a helyezések, Svédország az 5. (52 748 US dollárral, Magyarország a 23. (31 560 US dollárral).

Svédország mind a közlekedésbiztonság elméleti kérdéseinek kutatásában, mind a gyakorlati megvalósításokban példamutató. A közúti biztonság terén jelenleg mérvadó fejlesztési koncepció - a „Vision Zero” és a „Biztonságos Rendszerek” - kidolgozói és bevezetői szintén a svédek. Megemlítendő az is, hogy a közlekedésbiztonsági tevékenységet szabályozó ISO 39001 szabványt [3] elfogadó és a gyakorlat- 


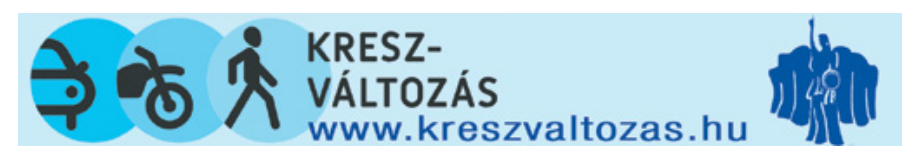

\begin{tabular}{|c|c|c|c|c|c|c|}
\hline $\begin{array}{l}\text { Életkori } \\
\text { csoport } \\
(\text { év - év) }\end{array}$ & $\begin{array}{c}\text { Meghaltak } \\
\text { száma(fö) } \\
\text { (Magyarország) }\end{array}$ & $\begin{array}{l}\text { Meghaltak } \\
\text { száma(fö) } \\
\text { (Svédország) }\end{array}$ & $\begin{array}{c}\text { Népesség } \\
\text { (fö) } \\
\text { (Magyarország) }\end{array}$ & $\begin{array}{l}\text { Népesség (fö) } \\
\text { Svédország }\end{array}$ & $\begin{array}{l}\text { Halálos sérülés } \\
\text { kockázata } \\
\text { (meghalt/millió } \\
\text { lakos) } \\
\text { (Magyarország) }\end{array}$ & $\begin{array}{l}\text { Halálos sérülés } \\
\text { kockázata } \\
\text { (meghalt/millió } \\
\text { lakos) } \\
\text { (Svédország) }\end{array}$ \\
\hline $0-17$ & 17 & 10 & 1,71 & 2,15 & 10 & 5 \\
\hline $18-24$ & 49 & 40 & 0,80 & 0,82 & 61 & 49 \\
\hline $25-44$ & 168 & 66 & 2,75 & 2,76 & 61 & 24 \\
\hline $45-64$ & 212 & 59 & 2,62 & 2,46 & 81 & 24 \\
\hline 65- & 174 & 78 & 1,90 & 2,00 & 96 & 39 \\
\hline Összesen & $620^{*}$ & 253 & 9,77 & 10,19 & 63 & 25 \\
\hline
\end{tabular}

*A magyar adatok a 2017-2019 évek adatainak éves átlagai. A svéd adatok 2017 évre vonatkoznak.

ban bevezető országok között az elsők között volt Svédország. (Erről a szabványról a hazai szakterületen kevés szó esik, elfogadása és bevezetése pedig - ismereteim szerint - eddig fel sem merült)

Van tehát jelentős különbség a fontosabb adatokban, elsősorban az, hogy magyar közúti közlekedésben 2017-ben 622 fö sérült meg halálosan, Svédországban pedig kevesebb, mint a fele 253 fö. (Zárójelben jegyzem meg, hogy a személygépkocsik motorizációs szintje 2016-ban Svédországban: 477 szgk/1000 lakos, Magyarországon: 338 szgk/1000 lakos). A lakosszám a két országban közel azonos, Svédország területe viszont közel ötször nagyobb, mint Magyarországé. A népsürüség $23 \mathrm{fö} / \mathrm{km}^{2}$ a svédeknél, Magyarországon pedig $105 \mathrm{fö} / \mathrm{km}^{2}$. A fövárosok lakosszáma közel azonos: 1,5 - 1,7 millió. Az adatok tehát különbözőek, de vannak hasonlóságok is.)

A közlekedésbiztonsági háttéradatok összehasonlítása akkor volna teljes, ha a két ország közúti infrastruktúrájával, a jármüállományával, nem utolsó sorban pedig a közlekedési, valamint a közlekedésbiztonsági kultúra jellemzőivel is foglalkoznánk. Nem lehet eleget hangsúlyozni a kulturált magatartás és a közlekedésbiztonság közötti szoros kapcsolatot. Ennek jelentőségét egyébként a hazai szakterületen is felismerték. Jó példa erre az utóbbi években rendszeresen megrendezett Közlekedési Kultúra Napja rendezvények sikere ${ }^{3}$.

A két ország néhány közlekedésbiztonsági mutatójának összehasonlítása - a meglévő különbségek ellenére is - tanulságos lehet. Hasznos következtetések vonhatók le, különösen most, hogy hamarosan számunkra is megkezdődik az új, hosszú távú, közlekedésbiztonsági stratégiai akcióprogram időszaka, (2021-2030) és baleseti helyzetünk javítása érdekében feltétlenül szükség van a legfontosabb hazai teendők átgondolására, részprogramjaink „újratervezésére".

Az 5. táblázatban a kockázatok számításához szükséges svéd és magyar adatokat gyűjtöttem össze.

A 3. ábra a két ország számított kockázati értékeit mutatja. (Az legidősebb életkori csoport ebben az ábrában a 65 évesnél idősebbek, mivel csak ilyen svédországi adat állt rendelkezése.) Minden életkori csoportban kisebb a halálos sérülés kockázata Svédországban, még a legfiatalabbak - a 17 évesnél fiatalabbak - között is, de a különbség a két ország adatai között itt a legkisebb. A következő életkori csoportban, mindkét országban a 18 -24 éves fiatalok

3 www.akozlekedesikulturanapja.hu 


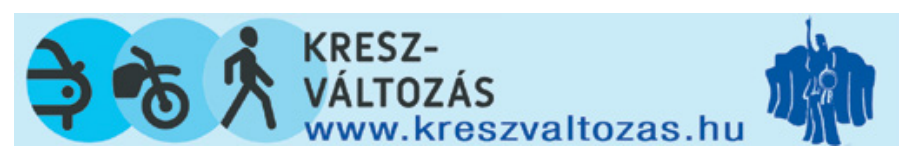

3. ábra: Halálos közúti baleseti sérülés kockázata Magyarországon és Svédországban (2017)

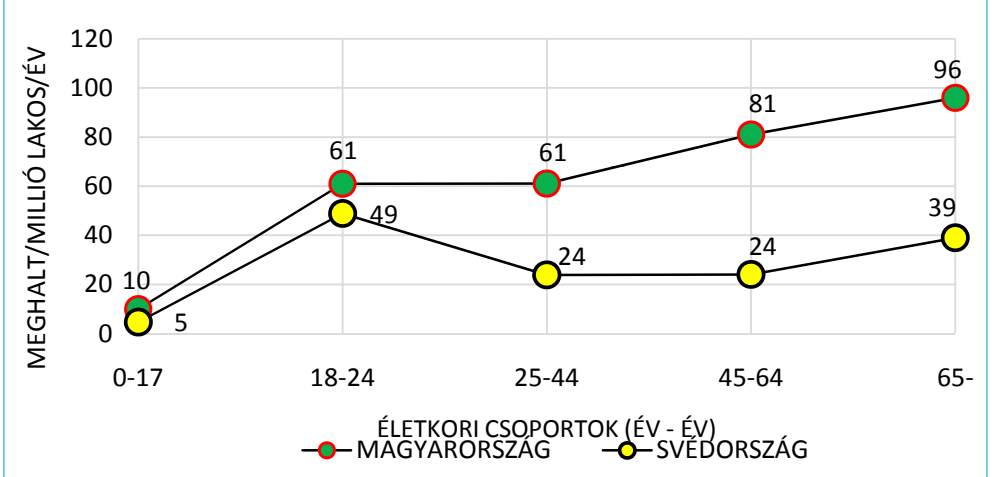

közúti balesetek során. A 6. táblázat adatait áttekintve, az egyes úthasználói kategóriákban jelentős eltérések adódnak a halálos áldozatok számában. Érdemes a „személygépkocsi utasok" és a "gyalogosok" csoportját is közlekedésbiztonsági szempontok alapján megvizsgálni.

A vizsgált évben 45 személygépkocsi utas halt meg Svédországkockázata jelentősen megnő, Svédországban kisebb, hazánkban nagyobb mértékben (49 61). A svédeknél ebben az életkori csoportban a legnagyobb a halálos sérülés kockázata, míg Magyarországon - az életkor növekedésével tovább növekszik. A két országban a 25-44 évesek kockázati mutatói között már nagy különbség mutatkozik. A svédeknél csökken a korábbi csoport adatához képest és a 45-64 éveseknél sem növekszik. Egészen más a helyzet Magyarországon, ahol további növekedés tapasztalható és a 45-64 évesek kockázata már 81 meghalt/millió lakos, több mint háromszor nagyobb, mint a svédeknél. A 65 évesnél idősebbek csoportjában a kockázat mindkét országban növekszik, a svédeknél 39 meghalt/ millió lakos, Magyarországon pedig 96 meghalt/millió lakos.

\section{A HALÁLOSAN MEGSÉRÜLTEK SZÁMA A KÉT ORSZÁGBAN A SÉRÜLTEK NEME SZERINT}

A 2017. évi adatok szerint Magyarországon a közúti közlekedési baleseteknek több mint kétszer annyi halálos áldozata volt, mint Svédországban. A 6. táblázatban a két ország adatait találjuk. Össze lehet hasonlítani, hogy az egyes úthasználói csoportban - férfiakat és nőket külön vizsgálva - mennyivel több az áldozatok száma Magyarországon. Átlagosan férfiak esetén: 449/196 = 2,29-szer több, nők esetében pedig: $173 / 57=3,03$-szor többen halnak meg hazánkban, mint Svédországban ban, Magyarországon pedig 100. A meghalt svéd utasok között 18/45=40\% volt nö, a magyar utasok közül arányosan lényegesen több, $58 / 100=58 \%$.

A halálosan megsérült gyalogosok száma különösen nagy a hazai közutakon. Svédországban összesen 37 gyalogos sérült meg halálosan, ugyanebben az évben Magyarországon 4,6szor több, 171 gyalogos. A halálosan megsérült férfi gyalogosok esetén még nagyobb a különbség. Svédországban 20, Magyarországon 105 meghalt gyalogos volt férfi. Ez 5,25-szörös különbség, ami feltűnően nagy, különösen, ha azt nézzük, hogy a férfi személygépkocsi -vezetők száma „csak” 1,9-szer vagy pl. a férfi személygépkocsi utasok száma „csak” 1,6-szor több, mint a svéd baleseteknél. Magyarországon 5,25-ször több a halálosan megsérült férfi gyalogos, mint Svédországban.

Nők esetében a legnagyobb különbség a kerékpárosoknál mutatható ki. Svédországban meg halálosan, Magyarországon 14. Ez azt jelenti, hogy a különbség 4,7-szeres. Ez utóbbi különbség értékeléséhez természetesen ismerni kellene a kerékpáros infrastruktúrában és forgalomban meglévő különbségeket is. Ezzel külön nem foglalkozom, de egyetlen adatot említek. 2017-ben Svédországban a 10 évnél fiatalabbak 85\%-a, az iskolába kerékpározó gyermekek 69\%-a, a munkahelyre közlekedő és a kerékpárosok közlekedésére kijelölt úttesegy évben összesen 3 női kerékpáros sérült 


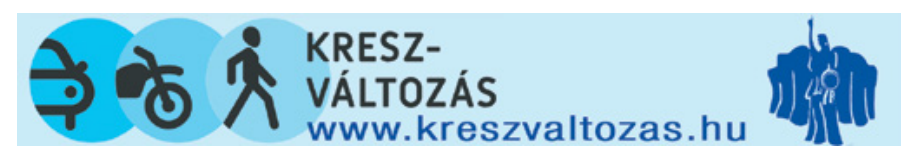

\begin{tabular}{|c|c|c|c|c|c|c|}
\hline & \multicolumn{3}{|c|}{ SVÉD ADATOK } & \multicolumn{3}{|c|}{ MAGYAR ADATOK } \\
\hline & Férfi & Nő & Összes & Férfi & Nő & Összes \\
\hline Személygépkocsi-vezető & 82 & 16 & 98 & 155 & 25 & 180 \\
\hline Személygépkocsi utas & 27 & 18 & 45 & 42 & 58 & 100 \\
\hline Kerékpáros & 23 & 3 & 26 & 67 & 14 & 81 \\
\hline Gyalogos & 20 & 17 & 37 & 105 & 66 & 171 \\
\hline Mopedes & 1 & 0 & 1 & 17 & 0 & 18 \\
\hline Motorkerékpáros & 37 & 2 & 39 & 41 & 1 & 42 \\
\hline Egyéb & 6 & 1 & 7 & 22 & 9 & 31 \\
\hline Mindösszesen & 196 & 57 & 253 & 449 & 173 & 622 \\
\hline Nők aránya (\%) & & $23 \%$ & & & $28 \%$ & \\
\hline
\end{tabular}

tet használó felnőtt kerékpárosok 40\%-a viselt kerékpár-bukósisakot.[2]. Erre vonatkozó hazai adat található a Közlekedéstudományi Intézet publikációjában. ${ }^{4}$ Eszerint Magyarországon a kerékpárosok mindössze 11,3\%-a használja a védősisakot és 3,4\%-a visel láthatósági mellényt.

A svéd és a magyar adatok további összehasonlítását mutatja a 4 . ábra, ahol az látható, hogy az összes halálosan sérült között milyen arányban szerepelnek az egyes közlekedő csoportok képviselöi a két országban. Nagyobb eltérés a „személygépkocsi-vezetőknél”, „gyalogosoknál” és „motorkerékpárosoknál” figyelhető meg. Mindkét országban a halálosan megsérültek között legnagyobb arányban a személygépkocsi-vezetők találhatók. A svédeknél nagyobb, (39\%), a magyaroknál pedig kisebb, (29\%) mértékben. A gyalogosok esetén más a helyzet. A hazai adatok szerint a meghalt gyalogosok részaránya $27 \%$, Svédországban lényegesen kisebb ez a részarány, mindössze $15 \%$, ami majdnem megegyezik a személygépkocsiban utasként életüket vesztett sérültek részarányával. A két országban gyakorlatilag azonos a motorkerékpárosként meghaltak száma. A 4.

4 www.akozlekedesikulturanapja.hu (Közlekedéstudományi Intézet: virtuális plakátkiállítás) ábrán a motorkerékpárosok részarányában azért van különbség, mert az összes halálosan megsérült száma jelentősen eltérő a két országban.

\section{HALÁLOS BALESETI SÉRÜLÉS KOCKÁZATA MAGYARORSZÁ- GON, NEMEK SZERINT}

Visszatérve a hazai adatokra, kiszámoltam külön a férfiakra és külön a nőkre érvényes halálos sérülési kockázati mutatók értékeit. (5. ábra). A 2. ábrán látható, hogy a halálos sérülés átlagos hazai kockázati tényezője hogyan alakult az egyes - választott - életkori csoportokban, az 5. ábra pedig ugyanazon életkori csoportokban a mutatók nemek szerinti megoszlását mutatja. A kockázati tényezők - mindkét nem esetén - folyamatosan növekednek az életkorral. Férfiaknál és a nőknél is legnagyobb a kockázat a 75 évesnél idősebbek között mutatható ki. A különbség azonban meglepően nagy. A 17 évesnél fiatalabbak között a kockázatok viszonylag kicsik, a férfiaknál kissé nagyobb (11), a nők esetén pedig kisebb (9). A 18-24 évesek korosztályában jelentősen nő a halálos sérülés kockázata és növekszik a nemek közötti különbség is. A férfiak kockázata már közel 3-szor nagyobb a nők kockázatán ebben az életkori csoportban. A 25-44 évesek csoportjában a férfiak kockázata tovább nő, a nőknél vi- 


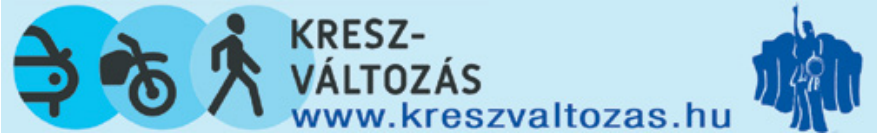

4. ábra: Halálosan megsérültek aránya a forgalomban betöltött szerepük szerint (2017)

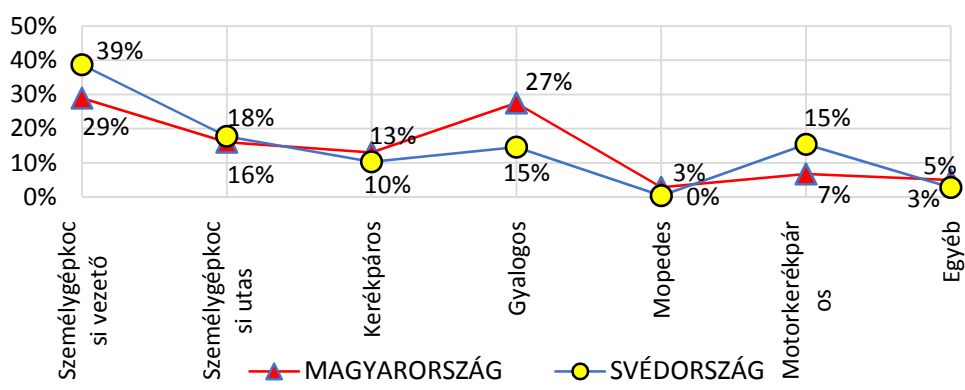

5. ábra: Férfiak és nők halálos közúti baleseti sérülési kockázata Magyarországon (2017-2019)

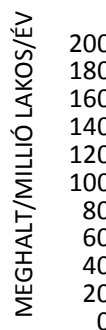

200
180
160
140
120
100
80
60
40
20
0

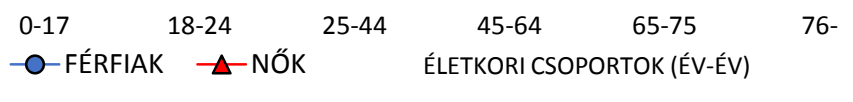

\section{6. ábra: Meghaltak nemek szerinti számaránya az egyes életkori csoportokban (az egyes életkori csoportokban összes meghalt $=100 \%$ )}

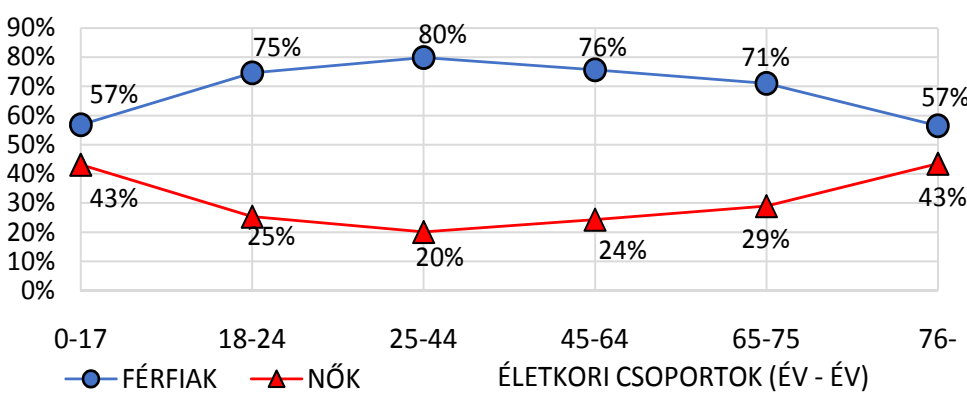

szont csekély mértékü csökkenés figyelhető meg. A továbbiakban az életkor növekedésével folyamatosan egyre nagyobb a halálos közlekedési baleseti sérülés kockázata. A 75 évesnél idősebb férfiak kockázata megdöbbentően nagy. 2017-2019 között a hazai közutakon 130 fö vesztette életét, akik 75 évesnél idősebbek voltak. Ebben az életkori csoportban Magyarországon 248 ezer fö él. A meghaltak száma évente átlagosan 130/3 fö volt, az évi átlagos halálos sérülési kockázat: $43,3 / 0,248=174,6$ meghalt/millió lakos.)

A nők lélekszáma ebben az életkori csoportban: 524 ezer fö, halálosan megsérült három év alatt 100 fö. Ezekkel az adatokkal számolva a halálos sérülés kockázata nők esetében, ebben az életkori csoportban: 63,6 meghalt/ millió lakos. (Az ábrában a számok kerekítve szerepelnek)

\section{HALÁLOSAN SÉRÜLT FÉR- FIAK ÉS NÖK SZÁMÁNAK ÉLETKORI CSOPORTO- KON BELÜLI MEGOSZLÁSA}

Az egyes életkori csoportokban meghalt férfiak/ nők arányát 


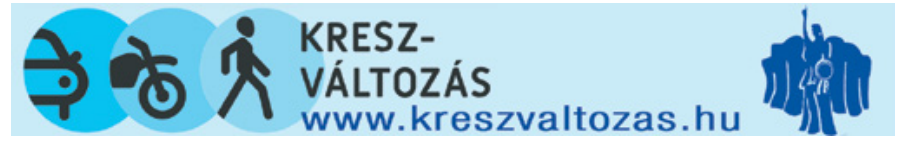

8. ábra: Férfiak és nők könnyti közúti baleseti sérïlésének
kockázata Magyarországon (2017-2019)

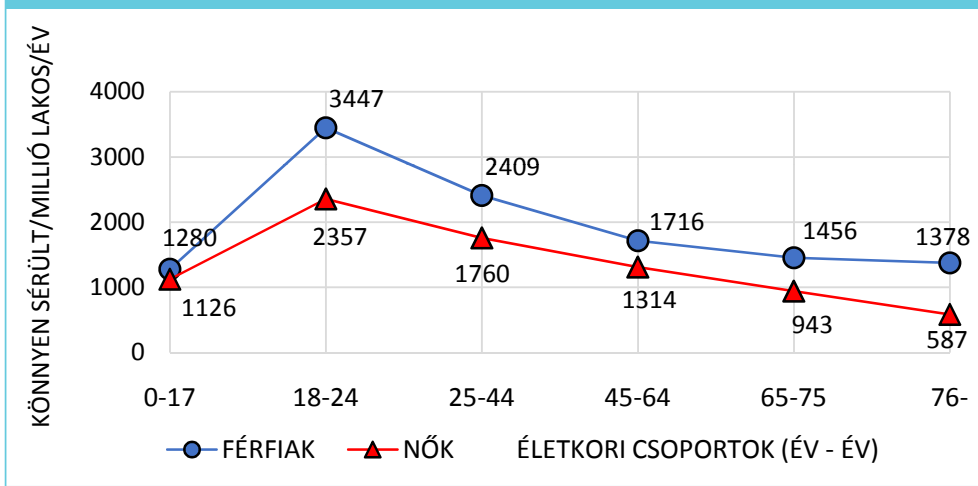

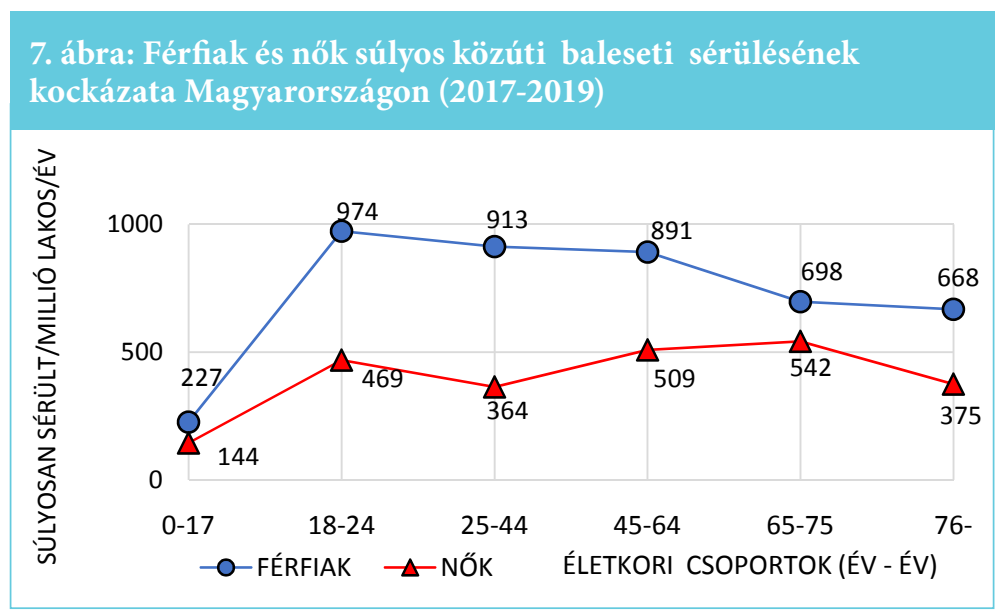

9. A SÚLYOS ÉS A KÖNNYÜ KIMENETELÜ SÉRÜLÉSEK KOCKÁZATAI

A korábbiakban a halálos sérülés számított kockázatával foglalkoztam. Érdemes szemügyre venni a hazai közlekedésben kialakult, súlyos és a könynyű sérülések kockázati mutatóit is. A 7. és 8 . ábra a számított adatokat mutatja. A férfiak és a nők mutatói közöti eltérések mind a súlyos, mind a könnyü kimenetelű sérülések esetén is megfigyelhetők, a különbségek azonban nem olyan nagyok, mint a halálos sérülések mutatóinál.

Nézzük elöször a férfiak mutatóit. Mindkét sérülési kategóriában a legnagyobb sérülési kockázat a 18-24 éves életkori csoportban. Ahogy korábban látmutatja a 6. ábra, ahol a különböző életkori csoportokban meghaltak száma látható nemek szerinti bontásban. Figyelemre méltóak a 25-45 éves korcsoportban tapasztalható arányok. A három vizsgált év alatt 402 férfi és 101 nő vesztette életét közúti közlekedési baleset következtében ebben a korcsoportban, (összesen 503 fö $=100 \%$ ). A 6. ábra mutatja, hogy ebben az életkori csoportban a legkisebb a nők számaránya (20\%), következéskép legnagyobb a férfiak aránya (80\%), vagyis az áldozatok döntően férfiak voltak. A többi korcsoportban ezek az arányok változnak, a 17 évesnél fiatalabb és a 76 évesnél idősebbek esetén a halálosan megsérült nők aránya a legnagyobb, egyformán $43 \%$. tuk, a halálos sérülés esetén ez nem így van, ott a 76 évesnél idősebbek kockázata a legnagyobb. (5. ábra)

A nők esetében a súlyos sérülés kockázata a 65-75 éves életkori csoportban a legnagyobb, a 75 évesnél idősebbeknél azonban csökken ez a mutató.

A könnyü sérülés kockázata mind a férfiak, mind a nők esetében a 18-24 éves korosztályban a legnagyobb. Ezt követően minden életkori csoportban folyamatosan csökken a könynyủ sérülés kockázati mutatója. 


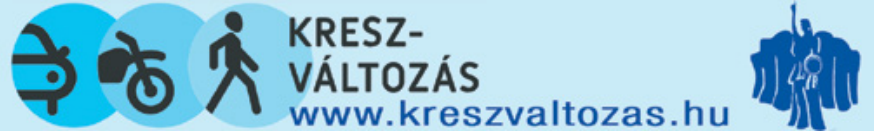

\section{0. ÖSSZEFOGLALÁS}

- 2019-ben a hazai „közúti baleseti mortalitás" 16\%-kal volt kisebb, mint 2010-ben. Ez a csökkenés azonban messze elmarad a 2020ra elvárt mértéktől. ${ }^{5}$ (1. táblázat)

- A 2017-2019 közötti hároméves hazai akcióprogram időszakában a halálosan megsérültek $27 \%$-a, a súlyosan megsérültek $37 \%$-a és a könnyen megsérültek 43\%-a nő volt. (1. ábra)

- A hároméves akcióprogram időszakában a halálos baleseti sérülés számított átlagos kockázata $63^{\star} 10^{-6}$. Legkisebb kockázata a 17 évesnél fiatalabbak, legnagyobb pedig a 75 évesnél idősebbek életkori csoportjában mutatható ki. (2. ábra)

- A 2017. évi svédországi és a hazai halálos sérülési kockázatok összehasonlításai jelentős különbségeket mutatnak. Legnagyobb eltérés a 45-64 éves életkori csoportban figyelhető meg. Svédországban ennek a csoportnak a halálos sérülési kockázata: 24 meghalt/millió lakos, Magyarországon pedig 81 meghalt/millió lakos. (3. ábra)

- 2017-ben Svédországban 253 fö, Magyarországon 622 fö vesztette életét közúti balesetek következtében. A 4. ábrán a két országban halálosan megsérültek számarányait, az áldozatok forgalomban betöltött szerepük szerint hasonlítottam össze. Svédországban a meghalt személygépkocsi-vezetők száma az összes áldozat számának 39\%-a, Magyarországon ennél kisebb, csak 29\%-a. A gyalogos áldozatok számarányát tekintve azonban más a helyzet. Svédországban az összes halálosan megsérült 15\%-a volt gyalogos, ugyanakkor Magyarországon ez az arány 27\%. A további hazai akcióprogramok kiemelt feladata kell legyen a halálosan megsérült gyalogosok számának jelentős csökkentése.

- Minden - vizsgált - életkori csoportban a férfiak halálos sérülési kockázata lényegesen nagyobb, mint a nőké. Az életkor növekedé-

5 A 2011-2020. időszakra vonatkozó EU Stratégiai Akcióprogram célkitüzése volt, hogy a 2020-ben közlekedési balesetekben elhunytak száma ne legyen több, mint a 2010-ben elhunytak számának fele. A tanulmány készítésekor még nem volt ismert a 2020. évi „eredmény”, de a 2019. évi adat ismeretében valószínütlen a célkitüzés teljesülése. sével mindkét nem csoportjában növekszik a kockázat számszerü értéke. A 75 évesnél idősebbek között a férfiak kockázata: $175^{\star} 10^{-6}$, a nők kockázata: $64^{\star} 10^{-6}$. (5. ábra)

- A különböző életkori csoportokban meghaltak számának nemek szerinti megoszlása változó. A 25-44 évesek csoportjában mutatkozik a legnagyobb különbség. (80\% - 20\%). Ebben a csoportban - 2017-2019 közötti három évben - Magyarországon összesen 503 személy szenvedett halálos sérülést, 402 férfi és 101 nő. (6. ábra)

- A súlyos baleseti sérülés kockázata minden életkori csoportban a férfiaknál nagyobb, mint a nőknél. A legnagyobb kockázat a férfiak esetén a 18-24 évesek között figyelhetö meg, $\left(974^{\star} 10^{-6}\right)$, nök esetén pedig a 65-75 évesek korcsoportjában. $\left(542^{\star} 10^{-6}\right)$. (7. ábra)

- A könnyü sérülés baleseti kockázata szintén minden életkori csoportban nagyobb a férfiaknál. Mindkét nem esetén a legnagyobb ez a kockázat a 18-24 éves életkori csoportban. (férfiak: $3447^{\star} 10^{-6}$, nők: $\left.2357^{\star} 10^{-6}\right)$. (8. ábra)

\section{FELHASZNÁLT IRODALOM}

[1] Ranking EU Progress on Road Safety (14 $4^{\text {th }}$ Road Safety Performance Index Report) June 2020. European Transport Safety Council

[2] Analysis of Road Safety Trends 2017. Management by objectives for road safety work towards the 2020 interim targets. TRAFIKVERKET (Swedish Transport Adninistration)

[3] INTERNATIONAL STANDARD. ISO 39001. Road traffic safety (RTS) management systems - Requirements with guidance for use. (Közúti közlekedésbiztonsági (RTS) menedzsment rendszerek Használati útmutatások.)

\section{The risk of road accident injuries in Hungary}

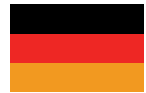

\section{Das risiko von verletzungen in strassenverkehrsunfällen in Ungarn}

